\title{
CARACTERIZACִÃO DAS INDICACִ̃̃ES CIRCUNSTANCIAIS EMITIDAS DURANTE ATIVIDADE DISCURSIVA POR UM PROFESSOR DE CIÊNCIAS: UMA LEITURA SEMIÓTICA
}

\author{
Carlos Eduardo Laburú* \\ Marcela Teixeira Godoy** \\ Andreia de Freitas Zômpero***
}

RESUMO: Baseados na teoria da Comunicação de Prieto, propomos uma transposição didática com o objetivo de estabelecer análises que permitam estruturar e compreender determinadas dinâmicas discursivas na escola. O principal conceito a ser destacado da teoria é o signo de tipo indicação circunstancial. Mostra-se que há atividades discursivas em que o professor se serve da emissão de indicações circunstanciais como instrumentos de interlocução para contextualizar o assunto e estimular a reflexão dos estudantes, tornando-os participantes ativos na construção do conhecimento. Fazendo uso de metodologia qualitativa, cinco aulas de um professor de ciências foram examinadas. Entre as várias emissões sígnicas produzidas pelo professor, é possível identificar signos qualificados de indicações circunstanciais que se apresentam com diversas características e fins instrucionais. Como se poderá constatar, o emprego das indicações circunstanciais se justifica por sua fundamental participação na contextualização discursiva e na função cognitiva com vistas ao aprimoramento conceitual dos aprendizes.

Palavras-chave: Educação científica. Semiótica. Sinais. Análise de discurso.

CIRCUMSTANTIAL INDICATIONS CHARACTERIZATION TRANSMITTED DURING DISCURSIVE ACTIVITY BY A SCIENCE TEACHER: A SEMIOTIC READING

ABSTRACT: Based on Prieto's theory of communication we propose a didactic transposition of its concepts to establish an analytical look to understand certain discursive dynamics in classroom. The main concept of the theory to be highlighted is circumstantial indication sign. In the discursive activities, it is shown that the teacher serves up of circumstantial indications emission as interlocution tools to contextualize and encourage discussion with students, thus making them active participants in constructing knowledge. Making use of qualitative methodology, five science teacher classes were examined. In moments of discursive process of these classes, and between various semiotic emissions produced by the teacher, it is possible to identify certain types of signs qualified as circumstantial indications that present different characteristics and purposes in education. As

*Universidade Estadual de Londrina, Londrina, Paraná, Brasil. Bolsita CNPq (processo 302281/2015-0), Departamento de Física. E-mail: laburu@uel.br

* * Universidade Estadual de Londrina, Londrina, Paraná, Brasil. Doutoranda do Programa de Pós Graduação em Ensino de Ciências e Educação Matemática. E-mail: biogodoy@yahoo.com.br

***Universidade do Norte do Paraná (UNOPAR), Londrina, Paraná, Brasil. Doutora pela Universidade Estadual de Londrina. Docente do Programa de Pós graduação em Ensino de Linguagens e tecnologias da UNOPAR. E-mail: andzomp@yahoo.com.br 
we will see, the use of circumstantial indications is justified by its fundamental role in cognitive function and discursive context in order to enhance the learners' concepts.

Keywords: Science Education. Semiotics. Signals. Discourse analysis. 


\section{INTRODUÇÃO}

As ocorrências educativas em sala de aula são comumente mediadas por alguma forma discursiva. Quando esta se manifesta via a dinâmica de interações dialógicas, pesquisas em educação científica têm mostrado que ela se torna um valioso mecanismo pedagógico de construção, aperfeiçoamento e aprofundamento dos significados dos conceitos científicos pelos estudantes (SCOTT; MORTIMER; AGUIAR, 2006). Bakhtin compreende o mecanismo dialógico como expediente para consubstanciar ideias novas (KUBLI, 2005, p. 503). Nutrido pelos signos organizados do grupo social que se encontra, esse mecanismo faz com que a consciência intelectual individual cresça. Em consonância com Bakhtin, Vygotsky (2007) igualmente assume que a consciência humana é construída socialmente e seu desenvolvimento se dá durante as trocas sociais por meio da linguagem, com isso cria um vínculo entre pensamento e linguagem. Ou seja, a linguagem auxilia a desenvolver e constituir o pensamento e vice-versa.

A participação do estudante na atividade discursiva leva à autonomia na elaboração do significado dos conceitos, cujo esforço de construção próprio torna a aprendizagem menos frágil e volátil do que se passivamente recebida. Ideias e mensagens somente são entendidas e assimiladas se puderem ser incorporadas a um sistema de significado pessoal e dando preferência à voz do aprendiz (KUBLI, 2005, p. 507). Em vista disso, coloca-se a importância do estabelecimento pelo professor de um ambiente educativo baseado na interlocução, a fim de que mais atenção seja dada às construções individuais, ideias e respostas dos aprendizes, condição para a formação de compreensões penetrantes e permanentes.

Ante a relevância instrucional do aspecto discursivo e da necessidade permanente de aperfeiçoar e trazer novas implicações pedagógicas às suas diversas dinâmicas, este trabalho faz uma leitura da obra de Prieto (1973), tendo em vista esses interesses. Da obra, vai se destacar o conceito de "indicação circunstancial", que será reinterpretado com a finalidade de permitir instrumentalizar e direcionar um olhar analítico diferenciado para a ocorrência de um tipo de signo emitido pelo professor quando encaminha determinadas dinâmicas discursivas em sala de aula. Diante dos objetivos de mostrar e explicar como se identificam os signos do tipo indicação circunstancial, suas diversas formas representacionais de manifestação, de situar seu papel instrucional variado e sua função cognitiva peculiar no discurso, este trabalho pretende se distinguir de estudos do gênero dado o seu viés semiótico utilizado.

As discussões abaixo foram estruturadas do seguinte modo. A parte teórica está dividida em quatro seções. A primeira pretende localizar o estudo na referência semiótica da comunicação, tratando-a como um entrelaçamento de sinais e significados. Uma vez que o interesse é a comunicação em sala de aula, a segunda seção resgata estudos em análise de discurso na educação científica, tema que posiciona o trabalho nas pesquisas da área. Dada a abordagem que trata de um tipo específico de análise discursiva, a terceira seção situa a questão das circunstâncias no processo discursivo e seu papel na compreensão das mensagens, tendo como base o referencial de Prieto (1973), complementado com outros autores. Essa seção fornece subsídios para o encaminhamento da seção 
subsequente, onde a ideia central do trabalho é colocada. Nela se ressignifica o conceito de indicação circunstancial de Prieto, mostrando que essa indicação é um tipo de sinal emitido pelo professor com a finalidade de não só de aclarar o discurso, mas provocar, fundamentalmente, uma forma de pensamento reflexivo do estudante com objetivo de levá-lo à compreensão dos conceitos tratados. Terminada essas apresentações, passa-se a descrever a metodologia utilizada e a análise dos dados. Durante a análise, são apresentados alguns casos de indicações circunstanciais manifestas por um professor de ciências em empreendimento discursivo, especificando e mostrando suas diversas características, finalidades e intencionalidade reflexiva. Com essas discussões, a proposta do trabalho de assistir a educação científica, com instrumentos conceituais inovadores que levem a compreender o papel de certos elementos discursivos durante o processo de comunicação em sala de aula, pretende ficar esclarecida. Por último, considerações finais encerram o estudo.

\section{FUNDAMENTAÇÃO TEÓRICA}

\section{Sinais, comunicação e significado}

Para Buyssens (1974), qualquer comunicação poderá assim ser chamada se houver por detrás dela uma intencionalidade em transmitir um significado. No seu entender, a comunicação nasce da intenção de um sujeito influenciar semelhantes para obter, por exemplo, uma colaboração, atender a uma necessidade ou dar a conhecer algo. Para satisfazer essas e outras exigências da vida social, os membros de um grupo humano precisam comunicar mensagens uns aos outros, que são transmitidas por meio de sinais.

De maneira geral, quando se está a falar em sinais se está a se referir a entidades sígnicas reconhecíveis, que formam uma classe de operações capaz de ser executada e destinada a dar a conhecer um estado de consciência particular com objetivo de influenciar outros (PRIETO, 1973, p. 10). Enquanto os sinais são representações semióticas exteriorizadas por meio de algum recurso perceptivo, as mensagens são aquilo que lhes transportam os significados.

Como à frente ficará evidenciado, é importante comentar que a noção de representação sígnica ultrapassa a natureza de plena linguagem com palavras, expressões etc. Inclui, ademais, desenhos, diagramas, fotos, mero gesto de correr para alcançar alguém, um evento físico qualquer, uma situação, um objeto ostentado, uma simples emoção ou qualquer sentimento ligado à qualidade vaga de sentir ternura, desejo, raiva, dor, entre outros. Por conseguinte, ao serem externadas emoções, ações involuntárias, reações, entre outras experiências, elas podem dar corpo ao pensamento de outrem, produzindo significados (SANTAELLA, 2005, p. 10). Por esse motivo, apresentam natureza sígnica, ainda que não possam ser chamadas de sinais pelas razões colocadas. Portanto, sinais são signos quando está envolvida a intencionalidade comunicativa.

Ao transmitir um sinal com desejo de comunicar uma mensagem específica, um emissor acaba por estabelecer sempre uma relação social de informação, 
interrogação ou ordem, provocando o que se denomina de ato comunicativo ou sêmico (PRIETO, 1973, p. 15; BUYSSENS, 1974, p.11). É na forma de ato sêmico que os indivíduos são capazes de concretizar seus estados de consciência. Mas, para que o ato seja bem-sucedido, os sujeitos a quem se destina a comunicação devem perceber, distinguir, selecionar e relacionar classes de mensagens e seus respectivos sinais.

No entanto, as experiências diretas de cada pessoa acerca de um mesmo objeto e sinal podem diferir, além do que a concretização da significação, para quem recebe o sinal, nunca é completa. Não obstante, os indivíduos são capazes de compartilhar compreensões semelhantes. Para isso, está à disposição um conjunto culturalmente pré-determinado de sinais que conseguem levar mensagens para que um comportamento desejado, e não outro, aconteça. Por intermediação desses sinais, os sujeitos conseguem decidir o que seu interlocutor quer dizer. São capazes de avaliar o grau em que dois significados são idênticos ou diferentes e de desempenhar a contento o esperado no processo de interlocução. O motivo de isso acontecer deve-se ao fato de que, a despeito de não existirem dois comportamentos ou dois estados de consciência idênticos, ainda assim, na infinita variedade do concreto, falantes são capazes de reconhecer estados de consciência um do outro por meio das mensagens dos sinais transmitidos. Isso se deve em razão de as pessoas conseguirem abstrair os elementos funcionais do ato comunicativo, ou seja, distinguem o que de mais essencial é apregoado, extraindo assim o significado (BUYSSENS, 1974, p. 51). Todavia, se os elementos em causa diferirem, também diferirá o significado que cada sujeito dá ao sinal. Devido a esses elementos funcionais poderem apresentar naturezas diversas como, por exemplo, quanto à composição, à relação de hierarquia, de conexão etc., na prática, a determinação dos significados se torna um empreendimento nada trivial e as diferenças no uso dos sinais por pessoas até do mesmo grupo social podem ser distintas. Daí, entre outros motivos, existirem falhas frequentes na reconstituição do estado de consciência de quem comunica e de torná-lo similar ao do seu destinatário.

Logo, o processo de comunicação envolve saber abstrair e concretizar significações, mas para aquele que recebe a comunicação tal processo nunca é pleno (BUYSSENS, 1974, p. 51, 85). O ponto básico aqui é que a natureza convencional da significação se estabelece por descoberta, por aproximação e constante refinamento do que há de comum aos estados de consciência dos indivíduos que se comunicam. Disso vem que o caráter culturalmente convencional de todo sinal transmitido numa composição discursiva ser incompleto, mas que, a qualquer momento, existe possibilidade de completar a significação na direção correta por recorrência a outros sinais, inclusive sinais que se fazem consolidados nas mais variadas formas representacionais como, por exemplo, na forma verbal, figurativa, matemática ou por meio de modelos, maquetes e objetos tridimensionais que Prain e Waldrip (2006, p. 1844) denominam resumidamente de representação 3D.

De maneira complementar ao que foi colocado, o enfoque psicológico de Vygotsky, por sua vez, associa signo e pensamento. No seu entender, a relação do homem com o mundo não é direta, mas intermediada por signos. Estes cumprem papel cognitivo de apoio à memória, funcionam como instrumento de mediação da linguagem, desenvolvendo o pensamento e ampliando nossa 
capacidade de ação sobre o mundo (OLIVEIRA, 1993). Sem a possibilidade de característicos e permanentes signos exteriores, enquanto apoio à memória, substitutos de representações próprias mais difíceis de distinguir e manejar, não haveria vida mental superior (HUSSERL, $1978^{1}$ citado por FIDALGO, 1998, p. 45). A consciência individual se alimenta dos signos, sendo seu crescimento deles derivado (KUBLI, 2005, p. 504). Para Peirce (1977² citado por ECO, 2003, p. 146), toda vez que pensamos temos presente na consciência algum sentimento, imagem, concepção ou outra representação que serve de signo, e o homem só consegue pensar por meio de palavras ou outros signos externos. Em resumo, o ser humano e o simbólico não se dissociam, e como lembra kubli (2005, p. 507), o próprio significado não se separa do reino dos signos trocados entre os membros de uma comunidade, não permanecendo restrito a uma mente individual.

Retomando o domínio da comunicação, para satisfazer às exigências variadas da vida social, as pessoas precisam trocar mensagens umas com as outras por meio de sinais. Devem ser capazes de distinguir classes de mensagens e sinais, além de estabelecer correspondência entre as duas sob pena de não atingirem o fim a que se propõem. Elas precisam estar de acordo quanto às classes a distinguir e às correspondências a estabelecer. Prieto (1973, p.11) coloca que tudo que se encontra no universo e possui uma significação para a criatura humana passou pelo significado dos sinais e foi ordenado por eles. São eles os auxiliares mais preciosos da inteligência e, por meio do apoio deles, o ser humano concebe o mundo exterior e transmite mensagens (significados) com a finalidade de exercer influência sobre outros membros do grupo social. Daí a importância de o processo comunicativo ser efetivado mediante atividade discursiva. Por esta se possibilita troca de mensagens, compartilhando significados. Uma vez que pela via discursiva se elaboram e se apuram os significados, discurso e significado são entidades inseparáveis. Para isso, a ação comunicativa joga com articulações sígnicas e atos sêmicos variados. No entrecruzar de gêneros discursivos variados e na diversidade de formas, graus, composições e articulações de diferentes representações, encontra-se a apropriação do significado (JAIPAL, 2010). Na reunião e convergência dos distintos gêneros e múltiplas representações, portanto, potencialidades cognitivas próprias são ativadas, maximizando o sentido do que se aprende. Daí a relevância de se compreender e qualificar tipos discursivos em sala de aula, visando um ensino e aprendizagem mais qualificados.

\section{Pesquisas em análise de discurso}

Estudos na temática análise de discurso em sala de aula apresentam um amplo campo de pesquisa, com diversos pontos de preocupação. A análise de discurso pertence à linguística, sendo que uma de suas linhas de pesquisa de interesse volta-se para a comunicação educacional. Em relação a esta última, podese citar o estudo de Sinclair e Coulthard (1975) como um dos primeiros a oferecer um esquema para analisar a dinâmica discursiva da sala de aula. Toda conversação em uma aula é capaz de apresentar um número finito de categorias discursivas com padrões funcionais e de qualidade relativos ao tipo de ensino encaminhado. Um padrão básico de falas em que se inicia com a fala do professor e que se visa uma 
resposta do estudante, com objetivo de que este dirija um comentário avaliativo para aquele, não pode ser ignorado (EDWARD; MERCER, 1993, p. 9). Pesquisas em educação científica com um interesse maior no conteúdo do que na forma serviram-se dessa estrutura eminentemente linguística para variados interesses de ensino e aprendizagem (CAPECCHI; CARVALHO, 2000).

De forma geral, por detrás dos estudos em análise de discurso educacional, reconhece-se o imperativo do estabelecimento de uma atmosfera de sala de aula de construção coparticipativa dos conhecimentos, em que os professores têm a tarefa de promover estudantes intrigados e encorajados a refletir suas ideias de maneira independente. Sob essa orientação, ações são incentivadas para estimular alunos questionadores e que evitem rotinas e critérios cegamente aprendidos. Por meio desse ideal de educação, encontra-se a defesa de um aprendiz crítico e que há muito tempo vem sendo propalado (SIEGEL, 1980). Na educação científica, em particular, persuadir os estudantes a procurar e suprir evidências e razões para as ideias que mantêm é sempre um fim a ser buscado, haja vista a natureza intrínseca do conhecimento científico (LEACH, 1999, p. 789). As qualidades relacionadas com a necessária articulação desse conhecimento ficam viabilizadas quando práticas de argumentação são utilizadas em contraponto à condição dos alunos ficarem apenas servindo como audiências dos seus professores (DRIVER; NEWTON; OSBORNE, 2000, p. 291). O engajamento em atividades de argumentação e explicação, colunas mestras do processo pedagógico de inquirir (KAWALKAR; VIJAPURKAR, 2013, p. 2005), ativa diversas habilidades cognitivas de caráter geral, como justificar posições, questionar, debater, analisar, avaliar, sintetizar, generalizar, habilidade de comunicar, resolver problemas, tomar decisões e criar hipóteses etc. (BAILIN, 2002, p. 362). Essencialmente, a argumentação é um processo dialógico (MALONEY; SIMON, 2006, p. 1818) e, por reunir todas as referidas habilidades, é necessária à racionalidade lógica em geral e, em particular, à racionalidade científica (OSBORNE; ERDURAN; SIMON, 2004, p. 995). A argumentação concorre para o desenvolvimento do pensamento crítico, lógico e de respeito às posições divergentes dentro de um ambiente de livre construção de ideias e proposições (SIEGEL, 1980).

Quando se fala em análise do discurso, Orlandi (1996) diz que não é um nível diferente de análise, pois o mesmo se dá quando pensamos em níveis como o fonético, o sintático ou o semântico. Mas, não se pode perder de vista que na análise de discurso a noção fundamental é a de funcionamento, ou seja, a análise de discurso visa destacar o modo como a linguagem funciona. O discurso é a língua funcionando para a produção de sentidos. Para Bakhtin (1992), o discurso é "diálogo vivo", por isso, está sempre voltado para a réplica, para a resposta que ainda não foi dita, mas que é provocada e, consequentemente, passa a ser esperada. $\mathrm{Na}$ atualidade, adotar a unidade discurso como objeto de estudo é compreender a amplitude do domínio da linguagem. É compreender o jogo interacional e ideológico no qual as manifestações linguísticas ocorrem, bem como as regulações de poder e saber às quais estão submetidas.

A partir da década de 1980, alguns estudos atribuíram um papel determinante às interações sociais no processo de construção do conhecimento. Tais interações envolvendo alunos e professores passaram a ser foco de estudo das teorias sócio 
cognitivas. Para muitos desses estudos, as teorias interativas de Vygotsky (2001, 2007) e Freire (2010) ressaltam a influência do meio social e cultural no processo de desenvolvimento humano e na linha de pensamento desses teóricos. Nesse sentido, Martins et al. $(2007,2008)$ trata o discurso na educação científica sob a perspectiva crítica. A autora defende que tal abordagem na educação científica deve viabilizar o estabelecimento de um espaço educativo participativo e dialógico, em que o educando sinta-se integrado na construção e reconstrução do processo de aprendizagem. Para isso, a conduta do educador deve ser, essencialmente, de mediação, de informação e de interação afetiva. $\mathrm{Na}$ abordagem crítica do discurso, o educador deve criar mecanismos de organização do processo de aprendizagem com atividades que permitam trocas de experiências, que valorizem a participação do educando e que busquem coerência entre valores, discurso e prática.

As contribuições teóricas a respeito do discurso, especialmente na educação científica, derivam da importância que lhe é atribuída nos processos cognitivos que podem ser provocados em sala de aula. Especialmente nos processos de construção de significados, o discurso é considerado um instrumento privilegiado de mediação do conhecimento científico (EDWARDS; MERCER, 1993; AGUIAR; MORTIMER, 2005; COLL; ONRUBIA, 1988; MARTINS et al., 2007; FONTANA, 2005; MORTIMER; SCOTT, 2002; LORENCINI JR., 1995). Sob uma perspectiva semiótica, o discurso em sala de aula permite com que os estudantes acessem os significados construídos entre si e os significados construídos pelos professores e vice-versa. Para Wells (1998, p. 115), o discurso na educação científica tem sido tratado como um fim em si mesmo em vez de ser visto pelo que é: simplesmente um dos meios - embora o mais importante - utilizados para atingir os objetivos de algumas atividades educacionais. Para o autor, o discurso na educação científica às vezes desempenha um papel auxiliar em operações não verbais, como, por exemplo, na realização de atividades experimentais e às vezes desempenha um papel constitutivo, como na maioria das discussões em sala de aula.

Para Coll e Onrubia (1998, p. 80) a atividade discursiva é a linguagem em ação, seja ela verbal ou escrita. Por meio de recursos semióticos, os participantes precisam tornar explícitos, para eles próprios e para os demais, os significados que elaboraram, estando obrigados a mostrá-los. Ou seja, a análise do discurso na educação científica é centrada na identificação dos mecanismos por meio dos quais os participantes - professor e alunos - usam a fala (e elementos extralinguísticos) para apresentar e reapresentar, uns aos outros, os conteúdos que são objetos do ensino e da aprendizagem em sala de aula. Logo, a natureza semiótica do discurso - concretizar o abstrato - ajuda a definir e redefinir a atividade conjunta ao longo do processo ensino-aprendizagem.

Segundo Monaco (2013, p. 209), o estilo discursivo do docente pode promover ou obstaculizar a construção de significados conceituais nos alunos. Mas, o significado e a função de uma determinada atividade discursiva na educação científica dependem do momento concreto do processo de construção da atividade conjunta em que são produzidos; do que foi dito e feito antes desse momento e do que for dito e feito depois. Assim, produções discursivas aparentemente idênticas podem cumprir - e é habitual que assim o façam - funções bem diferentes, 
dependendo do momento do processo no qual aparecem, ou seja, dependendo da sua localização na dimensão temporal da atividade. Daí a necessidade de levar em consideração essa localização.

\section{Papel das circunstâncias na comunicação}

Um sinal emitido, para ter sua mensagem compreendida, necessita ver-se inserido em um dado contexto. Essa é a maneira pela qual se é capaz de explicar por que alguém chega a compreender o que significa determinado ato linguístico. A corrente filosófica pragmatista iniciada por Peirce prestou especial atenção à relação entre os signos e seus utilizadores. O pragmatismo de Peirce entende que, para além das dimensões sintática e semântica da análise do processo sígnico, existe uma dimensão conjuntural de sua utilização, o que quer dizer que fora de um contexto o signo é inoperante. As regras pragmáticas estabelecem as condições a que o intérprete deve estar sujeito para que a mensagem de um sinal obtenha um sentido. Portanto, o significado das formas sígnicas passa não só pela análise sintática e pela consideração de valores semânticos, mas também pelas condições contextuais e situacionais de seu uso (FIDALGO; GRADIM, 2005, p. 99).

Assim, em comum a toda comunicação há um duplo, interdependente e inerente aspecto que deve ser considerado na mensagem trazida pelo signo. Um primeiro é não existir significado completo por si próprio e nem ele ocorrer isoladamente, mas se manter dependente de diferentes fontes de informação e de um domínio contextual de experiências e significados sociais (JAIPAL, 2010, p. 52). Então, uma mensagem específica que o emissor tenta transmitir necessita ser favorecida dentre outras diversas e diferentes mensagens, o que é possível pela indicação de um sinal e das circunstâncias que dirigem a atenção do receptor (PRIETO, 1973, p. 19). Prieto define circunstância como todo o fato que deve ser (re)conhecido pelo receptor no momento da ocorrência de algum ato sêmico. É todo contexto previamente sabido por ele anterior à emissão do sinal de um ato sêmico e que especifica a mensagem do sinal entre várias possíveis que carrega o mesmo sinal. Apenas uma indicação recebida de um sinal não basta para que o receptor possa atribuir uma mensagem determinada, pois o número de mensagens diferentes admitidas por um sinal é praticamente infinito. Desse modo, a indicação fornecida pela circunstância tem o objetivo de favorecer diferentemente as mensagens admitidas pelo sinal, fazendo com que o receptor conclua que a mensagem que o emissor transmite-lhe é, entre todas as mensagens admitidas pelo sinal, aquela que as circunstâncias favorecem mais (PRIETO, 1973, p. 18). Prieto ilustra o que se está a dizer quando se faz a pergunta "que horas são?" Uma resposta do tipo nove e meia está condicionada que receptor e emissor têm em comum certas circunstâncias que determinam se é de manhã ou noite (PRIETO, 1973 , p. 46). Outro exemplo, agora voltado para o ensino, seria o sinal relativo às palavras "sentido" ou "força" levar mensagens diferentes se o contexto é o campo conceitual da física ou da vida diária; a situação contextual da emissão de cada uma dessas palavras é que determina as mensagens específicas desses sinais. Por conseguinte, o receptor consegue selecionar uma mensagem de determinado sinal porque este sempre é produzido em circunstâncias delimitadas reconhecíveis 
pelo receptor no momento do ato sêmico e que lhe fornece indicação suplementar independente desse ato.

Em outras palavras, toda comunicação faz assunções sobre o que o destinatário deverá saber, tomando-as como base para ulterior interpretação. Grize (1982 ${ }^{3}$ citado por DUVAL, 2004, p. 91) complementa dizendo que não pode haver discurso cuja elaboração não leve em conta as representações reais ou supostas do seu destinatário presente ou virtual. Conforme também Buyssens (1974), de certa forma o comunicador considera que os signos são convencionais, pois escolhe dentre um repertório de possibilidades aquele que ele supõe existir simultaneamente na sua mente e na de seu intérprete (SANTAELLA; NÖTH, 2004, p. 94). Assim, o receptor da mensagem continuamente está a antecipar as expressões de outrem, preenchendo espaços vazios das falas, dos textos, das tarefas, prevendo ou pressupondo palavras que o interlocutor dirá ou não deveria ter dito ou que nunca mesmo dirá (ECO, 2003, p. 124). Simples proposições admitem mais de um sentido, pois o status que determina o lugar que ocupam na organização discursiva de um conjunto de proposições, ou o papel que jogam na expansão discursiva, depende da conjuntura da enunciação (DUVAL, 2004, p. 97). Portanto, caminhos diferentes para o significado podem ser atingidos uma vez que os indivíduos partem de diferentes condições iniciais de conhecimentos, experiências e perspectivas. Por isso, o efeito num sujeito devido a um signo, inclusive entendido no amplo sentido de um conceito ou mesmo de uma teoria científica, depende da história do sujeito, responsável por gerar uma interpretação. Ogdan e Richards (1989, p. 55) colocam que uma interpretação peculiar tem a ver com o contexto que afetou a pessoa no passado e se torna, a partir de então, uma experiência recorrente para ela. Consequentemente, qualquer interpretação é parte de um contexto psicológico por meio do qual o sujeito passa ou passou. Contexto que se constitui por uma somatória de eventos mentais, podendo ser imensamente numerosos, acidentais e separados no tempo. Mas, é graças a essa separação temporal que conexões com novos contextos podem ser efetuadas, surgindo novas recorrências e uniformidades parciais, possibilitando predições, inferências, reconhecimentos, generalizações indutivas, conhecimentos ou opiniões criativas (OGDAN; RICHARDS, 1989, p. 56). Devido a esses motivos, conclui-se que a comunicação é um empreendimento complexo, envolve pressuposições circunstanciais, que tanto o emitente quanto o destinatário precisam conhecer de eventos e entidades mais ou menos codificadas (ECO, 2003, p. 97). Tais pressuposições tomam parte do significado da expressão, muitas vezes se encontram implícitas e analiticamente inclusas, mas tendo o destinatário necessidade de descobri-las.

Junto às ideias anteriores, dois pontos adicionais podem ainda ser lembrados. Prieto (1973, p. 20) afirma que a condição preliminar de uma indicação, seja de um sinal ou das circunstâncias que o relacionam, é a existência de certa incerteza quanto a um fato em relação aos outros. Em função disso, é necessário diminuir essa incerteza dada as várias possibilidades entre as quais não se sabe qual a que se realiza efetivamente. A indicação propiciada pelas circunstâncias tem como intuito dissipar total ou parcialmente a incerteza da indicação do sinal, já que sempre sugere uma classe de possibilidades que deve ser realizada (PRIETO, 1973, p. 22). Prieto esclarece com o exemplo do tamanho relativamente grande 
de vestígios de pegadas de animais com formato de ferradura. Esses vestígios indicam que a possibilidade que se realiza pertence à classe de cavalos e não a qualquer outro equino ou animal. A indicação proporcionada pelo tamanho da ferradura, como membro do universo de um discurso, age de maneira não isolada para qualificar melhor a mensagem do sinal. O segundo ponto, complementar ao primeiro, tem a ver com o princípio da economia discursiva e que pode gerar incertezas. Diferentemente dos códigos não linguísticos, os códigos linguísticos, ao permitirem ao emissor adaptar a indicação do sinal às circunstâncias do ato sêmico, funcionam por intermédio desse princípio. Ou seja, dentro do princípio da parcimônia, o emitente, ao eleger um sinal conjugado a uma circunstância, o faz de modo suficiente para que o receptor compreenda o que ele quer dizer, com menos redundância possível (PRIETO, 1973, p. 124). Todavia, essa ação pode gerar problemas de compreensão.

Em síntese, ao receptor de um ato sêmico é imposto saber o propósito do emissor quando este lhe transmite uma mensagem. Esse propósito encontrase identificado tanto em razão da produção do sinal primário quanto das circunstâncias que acompanham colateralmente essa produção. Da confluência entre as indicações do sinal e das circunstâncias, o ato sêmico tende a se tornar bem-sucedido, o que em outras palavras significa existir boa compreensão, ou seja, a mensagem que o emissor tem a intenção de transmitir e a mensagem que o receptor atribui ao sinal convergem para uma única e mesma mensagem. Mas, por outro lado, em existindo fracasso do ato sêmico, questão que, sobretudo, interessa ao educador científico, é preciso reconhecer a origem desse fracasso para que se tomem ações para superá-lo. Prieto (1973, p.54) adianta sugestões nesse sentido ao explicar que o fracasso resulta não só de uma falsa apreciação das circunstâncias pelo emissor, mas pelo fato de ele acreditar que o receptor reconhece a indicação como sendo supostamente significativa tanto em relação ao sinal emitido quanto às circunstâncias que deveriam favorecê-lo. Logo, o ato sêmico malogra por não haver coincidência da mensagem que o sinal admite do ponto de vista do emissor, e que é imaginado por ele como sendo o mais favorecido pelas circunstâncias, mas que verdadeiramente deixa de sê-lo na perspectiva do receptor. Por conseguinte, no momento do ato sêmico, a falsa apreciação da circunstância imaginada pelo emissor, como sendo conhecida pelo receptor, não se constitui, de fato, circunstância. Somente na condição da indicação do sinal junto às indicações circunstanciais ser significativa para o receptor, este consegue perceber que a mensagem recebida pertence ao universo do discurso focalizado.

\section{Indicações circunstanciais na sala de aula}

Considerado o recorte dos elementos teóricos semióticos tratados, e com a intenção de adequá-los para uma leitura de ensino e aprendizagem, coloca-se o papel do professor em fazer com que os estudantes apropriem-se dos significados científicos que as mensagens carregam. No papel de mediador da emissão dos sinais dessas mensagens, o professor é o protagonista dessa ação. No momento em que procura fazer uso de indicações circunstanciais, ele potencializa a apropriação do significado das mensagens científicas transmitidas para o aprendiz, receptor do 
conhecimento. Porém, a partir desse instante, e com o propósito de adequar os termos que permitirão a leitura pretendida, os sinais passam a ser definidos como os constituintes sígnicos que formam o plano primário do discurso do locutor. Quer-se dizer com isso que os sinais vão se qualificar por constituírem a estrutura básica do discurso, sua espinha dorsal, apresentando-se de maneira primeira e supostamente evidente. Os sinais, portanto, são signos que têm a função de apontar explicitamente as mensagens colocadas na ação discursiva do professor. Eles são identificados pelos elementos comunicativos transmitidos de maneira imediata, direta, aberta e sem rodeios durante a interlocução com os estudantes.

Todavia, em distintas ocasiões discursivas e em concomitância com os sinais, é possível o professor aproveitar-se de indicações circunstanciais para subsidiar suas mensagens, com o objetivo de impelir o pensamento do estudante para melhor compreendê-las. Assim, passa-se a definir como indicações circunstanciais os constituintes sígnicos transmitidos que, em contraste com os sinais, atuam no corpo do discurso de modo indireto, oblíquo, enviesado, mas com o objetivo de contextualizá-las. Elas se sobressaem por evitar, num primeiro momento, a informação imediata, pronta e acabada fornecida pelo professor na forma de sinais. Ou seja, em vez de fornecer uma explicação direta, repetida, redundante ou mesmo reformulada para a explicação da mensagem, o professor opta pela emissão de uma indicação circunstancial com o intuito de levar o estudante a um esforço de pensamento para que autonomamente esclareça ou refine a mensagem do sinal que se encontra em processo de compreensão. Logo, por meio da intermediação de indicações circunstanciais, está-se a instigar mecanismos de inferência do estudante para que ele se aproprie da informação, resposta, ideia ou conclusão pretendida. Com a incumbência de esclarecer, estreitar, circunstanciar e tornar as mensagens dos sinais mais claras, a indicação circunstancial tem o propósito de fazer com que se consolide o entendimento do estudante, funcionando como indicador suplementar para subsidiar o receptor a selecionar e delimitar a mensagem que o emissor está atribuindo ao sinal. Como signos que atuam de modo auxiliar, as indicações circunstanciais participam então do discurso de maneira sugestiva ou dissimulada, visando sustentá-lo por demarcação e esclarecimento com o escopo de assistir, contextualizar e complementar as mensagens dos sinais para proporcionar-lhes um maior significado.

Por esses entendimentos, uma vez que na relação discursiva a transmissão do sinal inclina-se para um comportamento do aprendiz mais passivo e de dependência intelectual do professor, a prerrogativa da emissão da indicação circunstancial leva em conta, diversamente, o empenho reflexivo independente do estudante. Inclusive, a característica reflexiva de uma indicação circunstancial faz exigência de pensamentos de alto nível, tais como, a destacar, inferência abdutiva e raciocínios por correspondência associativa, por intermédio dos quais o estudante busca uma posição do que lhe foi dito. $\mathrm{Na}$ prática, as indicações circunstanciais podem se travestir de possíveis sugestões, pistas ou as chamadas "dicas" emitidas pelo professor, em que os estudantes devem tomar uma decisão ou realizar inferência por meio delas. Entretanto, é na associação complementar e dialética entre sinais e indicações circunstanciais que os significados do discurso vão se construindo, consolidando e sendo apropriados. 
Porém, é preciso dizer que o contexto discursivo adequado de sala de aula para emissão de indicações circunstanciais não pode ser qualquer, mas deve ter como referência abordagens educacionais progressistas, por isso é fundamental a iniciativa em direção ao compartilhamento coletivo do conhecimento (EDWARD; MERCER, 1993). Nesse sentido, uma vez que as indicações circunstanciais concorrem com objetivo de apurar e auxiliar na elaboração dos significados das mensagens transmitidas pelo professor, o seu emprego se mostra indissociável de tais abordagens educacionais, posto que precisam admitir atividades de ativa reflexão pelo próprio aprendiz. Vendo-se então inserida junto a uma proposta de construção compartilhada de conhecimento e de aprendizagem com significado, o emprego de um ensino na direção da construção e busca autônoma pelo estudante do conhecimento necessita estar colocado. Assim, metodologias baseadas no inquirir, consubstanciadas na forma de argumentação, explicação e questionamentos necessitam estar vigendo (KAWALKAR; VIJAPURKAR, 2013).

Uma vez estabelecida e justificada a importância subsidiária das indicações circunstanciais para a convergência da atenção e pensamento do aprendiz para compreensão dos significados dos sinais, por redução da ambiguidade e delimitação do universo do discurso do conceito científico ensinado, passa-se a apresentar resultados de um estudo que observa e analisa as emissões desses tipos de signos por parte do professor. No decorrer da exposição, será possível identificar suas ocorrências em contextos de ensino variados (sala de aula e laboratório), além de permitir revelar suas muitas características e finalidades instrucionais distintas que no momento discursivo precisaram se conformar. Antes, porém, esclarece-se a metodologia utilizada.

\section{METODOLOGIA}

Os dados abaixo foram obtidos a partir de quatro aulas de um mesmo professor de física realizadas em laboratório e outra ministrada em sala de aula convencional, todas filmadas para posterior análise qualitativa. Das aulas no laboratório, duas trataram de termologia, uma de hidrostática e outra de eletrostática. Nos dois primeiros assuntos, participaram estudantes do segundo ano e, no de eletrostática, participaram estudantes do terceiro ano do nível médio. As atividades experimentais de termologia e empuxo realizadas com os estudantes foram quantitativas e a de eletrostática baseou-se em estudo fenomenológico. $\mathrm{Na}$ aula convencional, o assunto abordado tratou de conceitos de cinemática para alunos do primeiro ano do referido nível escolar. No laboratório, os alunos estavam divididos em duas turmas, distribuídas na forma de seis grupos com três a quatro estudantes cada. $\mathrm{Na}$ aula convencional, em que as duas turmas estiveram reunidas, havia 41 estudantes. A escola era estadual e possuía perfil de classe média urbana. A metodologia de ensino utilizada pelo professor em todas as aulas se fundamentou na didática baseada no processo discursivo dialógico e de autoridade (SCOTT; MORTIMER; AGUIAR, 2006), concatenada com a metodologia de perguntas (COJOCARIU; BUTNARU, 2014). O professor, apesar de dominar essas metodologias de ensino, desconhecia a natureza do que estava sendo investigado, 
portanto, pode-se afirmar que as ocorrências analisadas foram espontâneas. Os momentos, abaixo selecionados, foram aqueles que evidenciaram melhor a aplicação do instrumento analítico. Esse instrumento, conforme convenção da seção anterior, identificou e separou os signos em sinais e indicações circunstancias e é à luz desses elementos que se realizaram as análises. A metodologia qualitativa de pesquisa, assim, possui caráter interpretativo.

\section{APRESENTAC̣̃̃O E ANÁLISE DE DADOS}

\section{Aula 1 - Indicação circunstancial por meio de ação}

Em uma aula de eletrostática, os estudantes foram compelidos a reproduzir experimentos demonstrativos realizados e explicados pelo professor, relacionados a processos de eletrização e diferenciação entre condutores e isolantes. Um dos experimentos consistia em eletrizar por contato uma placa metálica que se encontrava suportada por um canudinho de refresco. Além de servir de suporte para a placa, o canudinho é material isolante e tem a importante propriedade de conservar a carga elétrica colocada na placa. Contudo, um dos estudantes fracassou nessa tentativa, pois o canudinho do seu equipamento estava com problemas e a placa não permanecia eletrizada. Ao ser chamado para resolver o problema e explicar o que estava ocorrendo, o professor, sem mencionar nada e apenas agindo, segurou a placa pelo canudinho e tocou-a em um eletroscópio eletrizado. $\mathrm{O}$ aluno e seus colegas observaram que o eletroscópio descarregava pela mão do professor, pois ela funciona como um aterramento, como era de conhecimento dos estudantes. A partir de mais algumas repetições dessa observação, o professor questionou os estudantes sobre o motivo de o eletroscópio estar descarregando através da sua mão, visto que a placa se encontrava empunhada pelo canudinho. Um dos alunos respondeu prontamente que o canudinho não estava funcionando como material isolante, como era esperado que se comportasse, pois conduzia cargas. A partir dessa conclusão, o professor confirmou que o canudinho se comportava como material condutor e que estava com defeito, necessitando ser trocado.

$\mathrm{Na}$ solução do problema empírico ocorrido, o professor valeu-se do expediente de uma indicação circunstancial expressa simultaneamente por uma ação e uma pergunta. Por meio de tal recurso, aproveitou a oportunidade do momento problemático para realizar mais uma vez o aprimoramento do universo de discurso dos aprendizes em relação à temática isolantes e condutores elétricos. Em vez de fornecer a resposta direta para resolver o problema, portanto, repetindo sinais redundantes já comunicados, o professor estimulou sua inferência, lançando mão de uma indicação circunstancial com objetivo de auxiliar e complementar a compreensão autônoma dos conceitos correlacionados à temática estudada. Portanto, mediante a simultânea gesticulação e conjugada pergunta em cima da manipulação do equipamento, que levou a melhor evidenciar o que estava ocorrendo, constituiu-se uma indicação circunstancial com objetivo de direcionamento do raciocínio. Na contextualização discursiva, ao ser emitida, ela 
visou reforçar a mensagem e a competência experimental para com os conceitos físicos envolvidos.

\section{Aula 2 - Indicação circunstancial por meio de analogia}

Em uma atividade experimental a respeito do estudo do conceito de empuxo houve a necessidade de os estudantes medirem certa quantidade de água, usando uma seringa hipodérmica de $5 \mathrm{ml}$. Contudo, ao entornar a água na seringa, o volume ultrapassava a escala da seringa e isso fez com que um estudante perguntasse para o professor como medir o volume. Aproveitando-se de uma indicação circunstancial expressa na forma de pergunta, o professor questionou como o aluno faria para medir o comprimento da mesa do laboratório com a régua de $30 \mathrm{~cm}$ que estava sobre a mesa, visto que também a mesa não cabia na régua. Com a emissão dessa indicação circunstancial, o professor teve a intenção de que o estudante autonomamente resolvesse sua dúvida, sem que um sinal, traduzido por uma resposta direta, fosse colocado. Como se vê, o professor confiou que a analogia proposta pela indicação circunstancial, encaminhada na forma de pergunta, se encontrava dentro das possibilidades do universo de discurso do estudante e, portanto, deveria ser fato reconhecido pelo receptor e supostamente significativo para ele, favorecendo a compreensão do sinal "medir um volume maior que a capacidade da proveta".

\section{Aula 3 - Indicação circunstancial por meio de gesticulação}

Durante o estudo experimental da lei de Boyle-Mariotte (P.V = constante), os estudantes precisavam medir os volumes $(\mathrm{V})$ de um gás submetido a várias pressões $(\mathrm{P})$. Para levar a efeito o estudo, uma seringa de vidro hipodérmica de $20 \mathrm{ml}$ permanecia apoiada em pé em um suporte universal de laboratório e presa por uma pinça com mufa. Na cabeça do êmbolo da seringa, encontravase colada uma pequena e fina madeira que servia de plataforma para colocar tijolos de construção. Variando-se o número de tijolos sobre a plataforma, variava-se a pressão do gás. Para a obtenção do valor das pressões, fazia-se necessário determinar os pesos dos tijolos e dividi-los pela área do êmbolo da seringa ( $\mathrm{P}=$ pesos dos tijolos/área do êmbolo). No decorrer da atividade, um estudante perguntou se a área a ser utilizada para determinação da pressão era a da plataforma de madeira colada ao êmbolo. Diante do equívoco, o professor em vez de responder diretamente que a área deveria ser a do êmbolo e não a por ele mencionada, propôs debater a questão com toda a classe. Após o levantamento das ideias dos alunos e constatado que havia indecisão, o professor emitiu uma indicação circunstancial por meio de uma pantomima. Fazendo uso dessa representação, pediu para os alunos imaginarem que ele era o gás dentro da seringa. Fazendo gesticulações com as palmas das mãos, como se tivesse tocando as paredes internas da seringa em todas as direções, como se fosse o gás fazendo pressão sobre as paredes da seringa, lançou a seguinte questão juntamente com um movimentando de cabeça para cima, como se tivesse olhando por debaixo do êmbolo: “Qual área o gás 'está vendo’, para a medida da pressão, se está 
sofrendo os pesos dos tijolos?" De imediato a resposta desejada foi enunciada por vários alunos e ratificada pelo professor.

Pela indicação circunstancial encaminhada por meio de pantomima, o professor procurou reforçar, dentro do universo discursivo em exame, que a possibilidade da área a se realizar deveria ser aquela do êmbolo que o gás está submetido e não a da plataforma de madeira mais à vista. Com as possíveis áreas em jogo no plano do indicante, o professor buscou junto ao recurso de uma pantomima, dirigir a atenção da classe para o estabelecimento de uma área específica, favorecendo, assim, por meio de indicação circunstancial (gesticulação), que o sinal (conceito de pressão) fosse corretamente considerado. Dessa forma, fez com que os estudantes chegassem à conclusão de que a mensagem transmitida se tratava, entre todas as mensagens admitidas pelo sinal, daquela que a circunstância mais favoreceu.

\section{Aula 4 - Indicação circunstancial por meio de representação 3D}

No final das discussões a respeito de um experimento para medir o coeficiente de dilatação volumétrica de um líquido $[\mathrm{g}=(\mathrm{Vo})-1$.(DV/DT)], em que os estudantes já haviam determinado experimentalmente a relação DV/ DT por meio da inclinação do gráfico da variação do volume pela temperatura, o professor questionou a classe acerca do que ainda era necessário para obter o coeficiente de dilatação volumétrico (g). Durante esse questionamento, ele destacou novamente a fórmula " $\mathrm{g}=(\mathrm{VO})$-1.(DV/DT)" para determinação desse coeficiente, reescrevendo-a na lousa. Muitos estudantes, orientados pela fórmula, prontamente responderam que era preciso achar o volume inicial do líquido (Vo). $\mathrm{Na}$ sequência, o professor perguntou como medir esse valor, mas, sem obter resposta após um tempo de espera (NERI DE SOUZA, 2009), complementou a pergunta, inquirindo sobre qual material, dos disponíveis sobre a mesa dos grupos, poderia servir para essa finalidade e que estava ocioso até aquele momento.

Após isso, alguns estudantes mostraram ou responderam apontando para a proveta de $100 \mathrm{ml}$, equipamento que ainda não havia sido utilizado pelos alunos e que não entrara nas discussões até aquele instante. Desse processo interativo discursivo, nota-se que, compondo com a pergunta colocada, a presença real e igualmente simbólica ostentada pela proveta, entre vários materiais à frente dos alunos, é manifestação de uma indicação circunstancial com a finalidade de compreender e dar resposta ao problema instigado. A indicação circunstancial que se materializa na existência da proveta propicia um indício para que a possibilidade que se realiza em relação ao sinal transmitido (medir o volume inicial [Vo]), entre todas as possibilidades de todos os objetos existentes, seja aquela que mais satisfaz. Por conseguinte, em razão de o contexto de ensino remeter à proveta a categoria de indicador circunstancial, é por meio desse papel simbólico que ela opera para auxiliar a delimitar o entendimento da mensagem do sinal que, no caso, busca a solução do problema. Em outras palavras, a indicação circunstancial, agora caracterizada na forma de representação 3D, conforme denominação reportada pelo referencial de multimodos e múltiplas representações (Prain; Waldrip, 2006, p. 1844), foi a maneira como o professor se serviu para evitar uma simples resposta 
direta sua e forçar, por outro lado, o pensamento de seus estudantes a resolver independentemente a questão presente.

\section{Aula 5 - Indicação circunstancial por meio de gesticulação}

Após a aula teórica de cinemática, um exercício aplicativo do conteúdo pedia para que os estudantes determinassem, em um gráfico de espaço pelo tempo desenhado na lousa, os instantes em que o movimento de um móvel era uniforme. O gráfico apresentava uma função com trechos lineares e não lineares no tempo. Percebida a dificuldade dos alunos para responder o exercício, o professor, por meio de questionamentos fechados de baixo nível (COUTINHO; ALMEIDA, 2014), resgatou a memória dos alunos a respeito dos conceitos tratados ao mesmo tempo em que reescreveu a fórmula "V $=\operatorname{tgq}=\mathrm{DS} / \mathrm{DT}=$ constante", deixando-a bem explícita na lousa. Com a palma da mão estendida encenando uma régua e sem dizer mais nada, fez gestos que tocavam tangencialmente vários pontos do gráfico. Assim, com tais gestos, o professor procurou indicar que a possibilidade que deveria se realizar, referente ao movimento uniforme, deveria ser aquela composta pelas possibilidades das tangentes que não variam $(\mathrm{V}=\operatorname{tgq}$ $=$ constante) nos intervalos de tempo. Com ambas as possibilidades em jogo no plano do indicante, isto é, fórmula escrita na lousa e gestos com palma da mão, o professor buscou dirigir a atenção da classe para o estabelecimento do universo do discurso retratado pela não variação das tangentes, portanto, para os instantes, equivalendo as não variações das velocidades, favorecendo, assim, a circunstância admitida pelo sinal (instantes de movimento uniforme).

Dessa forma, sua intenção foi fazer com que os aprendizes concluíssem que a mensagem transmitida era, entre todas as mensagens admitidas pelo sinal, aquela que as circunstâncias (associação entre as indicações dos gestos em cima dos gráficos e destaque da fórmula "V $=\operatorname{tgq}=\mathrm{DS} / \mathrm{DT}=$ constante") mais favorecessem a solução e compreensão do sinal (discriminar os intervalos de movimentos uniforme).

\section{CONSIDERAC̣ÕES FINAIS}

Como se pôde perceber, o estudo se distingue dos trabalhos do gênero dada sua perspectiva semiótica distinta. Seu objetivo foi propor um olhar analítico firmado em elementos semióticos, com a intenção de organizar e entender diligências discursivas dialógicas decorrentes das interações do professor de ciências com seus estudantes em sala de aula. Ao explicitar e caracterizar a ocorrência da indicação circunstancial durante a emissão de sinais para a apropriação do significado da mensagem científica transmitida pelo professor, permitiu-se revelar sua importância dentro da situação de ensino ocorrida. Primeiramente, por possuir papel auxiliar e complementar para a compreensão dos sinais na medida em que os circunstancia na narrativa. Posteriormente, como elemento ativador de pensamentos de maior nível do aprendiz, ao fazer uso de inferências para encaminhar seus raciocínios com a finalidade de compreensão dos conceitos científicos. 
Como se verifica pela análise dos dados, as indicações circunstanciais são capazes de se manifestar em diferentes formas representacionais, caracterizandose, nos casos estudados, na forma de gesticulações, ações, verbalizações e representação 3D, todas direcionadas por questionamentos com o objetivo estimular o raciocínio mais profundo do estudante para que a mensagem científica transmitida seja apreendida.

Muito provavelmente, lançar mão de indicações circunstanciais em situações quotidianas e frequentemente imprevistas de sala de aula, seguramente, não é uma tarefa fácil para todo professor. Mas, conforme for adquirindo experiência com o conteúdo e estiver compromissado com um formato de ensino discursivo mais aberto e questionador, esse obstáculo tende a se reduzir. Isso porque o professor se torna capaz de antever muitas dificuldades dos estudantes em pontos específicos da matéria e, em razão disso, é capaz de empregá-las em momentos pertinentes da sua interlocução com os estudantes. E ao estar consciente da natureza e da dinâmica dos elementos comunicativos aqui estudados, igualmente se mostra melhor preparado pedagogicamente para utilizá-los, do que quando o fizer de maneira impensada.

Decerto, o emprego do instrumento das indicações circunstanciais potencializa uma maior qualidade da aprendizagem dos estudantes, meta que deveria estar no horizonte daquele que ensina.

\section{NOTAS}

${ }^{1}$ HUSSERL, Edmund. Philosophie der Arithmetik. Logische und Psychologische Unter-suchungen. The Hague: Nijhoff, 1978.

${ }^{2}$ PEIRCE, Charles Sanders. Collected Papers. Cambridge: Harvard Un. Press, 1977. (trad. bras., Semiótica, São Paulo, Perspectiva).

${ }^{3}$ GRIZE, J. B. De la logique à l'argumentation. Pariz: Droz, 1982.

\section{REFERÊNCIAS}

AGUIAR JR., O. G.; MORTIMER, E. F. Tomada de consciência de conflitos: análise da atividade discursiva em uma aula de ciências. Investigações em Ensino de Ciências, Porto Alegre, 10, 2, p. 179-207, 2005. Disponível em: <http://www.if.ufrgs.br/public/ensino/revista.htm>. Acesso em: 9 mar. 2014.

BAILIN, S. Critical thinking and science education. Science \& Education, Netherlands, 11, p. 361-375, 2002.

BAKHTIN, M. Marxismo e filosofia da linguagem. 6. ed. Tradução de M. Lahud e Y. T. Vieira. São Paulo: Hucitec, 1992.

BUYSSENS, E. Semiologia \& comunicação linguística. São Paulo: Cultrix, 1974.

CAPECCHI, M. C. V. M.; CARVALHO, A. M. P. Argumentação em uma aula de conhecimento físico com crianças na faixa de oito a dez anos. Investigações em Ensino de Ciências, Porto Alegre, v. 5, n. 3, p. 171-189, 2000. 
COJOCARIU, V. M.; BUTNARU, C. E. Asking questions: critical thinking tools. Procedia - Social and Behavioral Sciences, Amsterdam, v. 128, p. 22-28, 2014.

COLL, Cesar; ONRUBIA, Javier. A construção de significados compartilhados em sala de aula: atividade conjunta e dispositivos semióticos no controle e no acompanhamento mútuo entre professores e alunos. In: COLL, C. (Org.). Ensino, aprendizagem e discurso em sala de aula. Porto Alegre: ArtMed, 1998. p. 143-169.

COUTINHO, M. J.; ALMEIDA, P. A. Promoting student questioning in the learning of Natural Sciences. Procedia - Social and Behavioral Sciences, Amsterdam, v. 116, p. 3781-3785, 2014.

DRIVER, R.; NEWTON, P.; OSBORNE, J. Establishing the norms of scientific argumentation in classrooms. Kawalkar, v. 84, p. 287-312, 2000.

DUVAL, R. Semiosis y pensamiento humano: registros semióticos y aprendizajes intelectuales. Colombia: Universidad del Vale, 2004.

ECO, H. Tratado geral de semiótica. São Paulo: Perspectiva, 2003.

EDWARDS, D.; MERCER, N. Common knowledge: the development of understanding in the classroom. London: New York: Routledge, 1993.

FIDALGO, A. Semiótica: a lógica da comunicação, 1998. Disponível em: <www.bocc.ubi.pt > Acesso em: 9 out. 2005.

FIDALGO, A.; GRADIM, A. Manual de semiótica, 2005. Disponível em: <www.ubi.pt>. Acesso em: 9 out. 2005.

FONTANA, R. Ap. C. Mediação pedagógica na sala de aula. Campinas: Autores Associados, 2005. FREIRE, P. Pedagogia da autonomia: saberes necessários à prática educativa. São Paulo: Paz e Terra, 2010. JAIPAL, K. Meaning making through multiple modalities in biology classroom: a multimodal semiotics discourse analysis. Science Education, London, 94, p. 48-72, 2010.

KAWALKAR, A.; VIJAPURKAR, J. Scaffolding Science Talk: the role of teachers' questions in the inquiry classroom. International Journal of Science Education, London, v. 35, n. 12, p. 2004-2027, 2013.

KUBLI, F. Science teaching as dialogue: Bakthin, Vygotsky and some applications in the classroom. Science \& Education, Netherlands, v. 14, p. 501-534, 2005.

LEACH, J. Students understanding of the co-ordination of theory and evidence in science. International Journal of Science Education, London, 21, 8, p. 798-806, 1999.

LORENCINI JR., A. O ensino de ciências e a formulação de perguntas e respostas em sala de aula. In: TRIVELATO, S. L. F. (Org.). Coletânea Escola de Verão para professores de prática de ensino de física, química e biologia. São Paulo: FEUSP, 1995. p. 105-114.

MALONEY, J.; SIMON, S. Mapping children's discussions of evidence in science to assess collaboration and argumentation. International Journal of Science Education, London, v. 28, n. 15, p. 1817-1841, 2006.

MARTINS, Isabel et al. Contribuições da análise crítica do discurso para uma reflexão sobre questões do campo da Educação Ambiental: olhares de educadores em ciências. Pesquisa em Educação Ambiental, São Paulo, v. 3, n. 1, p. 129-154, 2008.

Contributions from critical perspectives on language and literacy to the conceptualization of scientific literacy. In: LINDER, Cedric; ÖSTMAN, Leif; WICKMAN, Per-Olof (Ed.). Promoting scientific literacy: science education research in transaction proceedings of the Linnaeus Tercentenary Symposium. Sweden: Uppsala, 2007.

MONACO, Sebastián. Compreender la educación para enseñar mejor: acciones docentes apoyadas em la psicolinguística. Enseñanza de las ciências, Barcelona, n. 31.2, p. 209-227, 2013.

MORTIMER, E. F.; SCOTT, P. Atividade discursiva nas salas de aula de Ciências: uma ferramenta sociocultural para analisar e planejar o ensino. Investigação em Ensino de Ciências, Porto Alegre, 7, 3, p. 283-306, 2002. Disponível em: <http://www.if.ufrgs.br/public/ensino/revista. htm>. Acesso em: 15 maio 2015. 
NERI DE SOUZA, F. Questionamento activo na promoção da aprendizagem activa. In: VII ENCONTRO NACIONAL DE PESQUISA EM EDUCAÇÃO EM CIÊNCIAS, 2009, Florianópolis. Anais... Belo Horizonte: ABRAPEC, 2009. p. 1-12. OGDAN, C. K.; RICHARDS, I. A. The meaning of meaning. USA: HBJ, 1989.

OLIVEIRA, M. K. Vygotsky, aprendizado e desenvolvimento: um processo sócio-histórico. São Paulo: Scipione, 1993. (Série Pensamento e Ação no Magistério).

ORLANDI, E. P. A linguagem e seu funcionamento: as formas do discurso. Campinas, SP: Pontes, 1996.

OSBORNE, J.; ERDURAN, S.; SIMON, S. Enhancing the quality of argument in school science. Journal of Research in Science Teaching, USA, v. 41, n. 10, p. 994-1020, 2004.

PRAIN, V.; WALDRIP, B. An exploratory study of teachers 'and students' use of multi-modal representations of concepts in primary science. International Journal of Science Education, London, v. 28, n. 15, p. 1843-1866, 2006.

PRIETO, L. J. Mensagens e sinais. São Paulo: Cultrix, 1973.

SANTAELLA, L. Semiótica aplicada. São Paulo: Thomson, 2005.

SANTAELLA, L.; NÖTH, W. Comunicação \& semiótica. São Paulo: Hacker, 2004.

SCOTT, P. H.; MORTIMER, E. F.; AGUIAR, O. G. The tension between authoritative and dialogic discourse: a fundamental characteristics of meaning making interactions in high science lessons. Science Education, London, v. 90, n. 7, p. 605-631, 2006.

SIEGEL, H. Pensamento crítico como ideal de educação. The Educational Forum, São Paulo, Faculdade de Educação da Universidade de São Paulo, 1984. p. 1-23. (Cadernos de Didática, n.1, v. XLV, p. 7-23, nov. 1980).

SINCLAIR, J. McH; COULTHARD, R. M. Towards an anlalysis of discourse: the english used teachers and pupils. London: Oxford Univesity Press, 1975.

VYGOTSKY, L. S. A formação social da mente: o desenvolvimento dos processos psicológicos superiores. São Paulo: Martins Fontes, 2007.

. A construção do pensamento e da linguagem. São Paulo: Martins Fontes, 2001.

WELLS, Gordon. Da adivinhação à previsão: discurso progressivo no ensino e na aprendizagem de ciências. In: COLL, C. (Org.). Ensino, aprendizagem e discurso em sala de aula. Porto Alegre: ArtMed, 1998. p. 143-169.

Recebido: 09/06/2015

Aprovado: 31/08/2016

Contato:

Carlos Eduardo Laburú

Universidade Estadual de Londrina

Departamento de Física, CCE

Rodovia Celso Garcia Cid Pr 445 km 380

Campus Universitário

Fone: (43) 33714266 FAX 33714166

Caixa Postal 10.011, CEP 86057-970, Londrina, PR

laburu@uel.br 